\title{
A CRITICAL DISCOURSE ANALYSIS OF AN ESSAY: EMPLOYING RUTH WODAK'S MODEL
}

\author{
Ameer Ali ${ }^{1}$, Muhammad Ibrahim² \\ University of Sindh, Jamshoro, Pakistan. \\ 1 ameer7037@gmail.com \\ ${ }^{2}$ ibrahimsoomrogic@gmail.com
}

\begin{abstract}
Critical Discourse Analysis demystifies power mechanisms operating in different kinds of discourse. It sets forth hidden discourses and meanings for common people. Besides, the current research assignment has studied Bernard Lewis' essay: The Roots of Muslim Rage using Ruth Wodak's Discourse Historical Model (2004). Moreover, the researchers have employed purposive sampling as a research design to collect the data. The research is qualitative as it answers the research questions using Wodak's model. The purpose of this research was to expose hermeneutic interpretations of orientalist discourse that reflect implausible thinking about Muslims. However, much work has been done on the discourse of orientalism, yet from Wodak's point of view much work is to be done; hence, the current research paper has also contributed to the field of critical discourse analysis. The subjectification of the Muslims through oriental norms is the main theme in Lewis' essay as revealed by analyzing lexical and syntactic units. Thus, the current research has concluded the findings in accordance with the research questions and research objectives.
\end{abstract}

Keywords: discourse, implausible, norms, hermeneutic, power.

\begin{abstract}
ABSTRAK
Analisis Wacana Kritis menunjukkan mekanisme kekuasaan yang beroperasi dalam berbagai jenis wacana. Ini mengemukakan wacana dan makna tersembunyi bagi orang awam. Selain itu, tugas penelitian saat ini telah mempelajari esai Bernard Lewis: The Roots of Muslim Rage menggunakan Model Wacana Sejarah Ruth Wodak (2004). Selain itu, peneliti telah menggunakan purposive sampling sebagai desain penelitian untuk mengumpulkan data. Penelitian ini kualitatif karena menjawab pertanyaan penelitian menggunakan model Wodak. Tujuan dari penelitian ini adalah untuk mengekspos interpretasi hermeneutik wacana orientalis yang mencerminkan pemikiran yang tidak masuk akal tentang Muslim. Namun, banyak pekerjaan telah dilakukan pada wacana orientalisme, namun dari sudut pandang Wodak banyak pekerjaan yang harus dilakukan; oleh karena itu, makalah penelitian saat ini juga berkontribusi pada bidang analisis wacana kritis. Subjektivitas Muslim melalui norma-norma oriental adalah tema utama dalam esai Lewis sebagaimana diungkapkan dengan menganalisis unit leksikal dan sintaksis. Dengan demikian, penelitian saat ini telah menyimpulkan temuan sesuai dengan pertanyaan penelitian dan tujuan penelitian.
\end{abstract}

Kata kunci: wacana, tidak masuk akal, norma, hermeneutik, kekuasaan. 


\section{INTRODUCTION}

Human language is not only a tool of communication and transmitting information, but it is also an armoury of the human brain that helps create discourse and subjectivity. Daily life interaction, academic lectures, political speeches, religious sermons, news broadcast, and written literature are the different ways people make use of language. From communication, the transmission of information to the representation of reality, language plays a very vital role in our life. Therefore, linguists have taken a keen interest in the study of language. They study language semantically, phonologically, syntactically, and pragmatically. In recent times, the field of critical discourse analysis is playing a main role in analyzing the language with respect to the mechanisms of power. Similarly, the interest of the current research lies in critical discourse analysis.

Mostly, the use of language is subject to protecting socio-political interests, propagating some religious ideologies, or advancing certain academic theories (Foucault, 2012). Moreover, this contextual use of language, in Foucauldian terminology, imposes restrictions on the production of language; this restricted employment of language generates discourse (Foucault, 2012). These restrictions always function as mechanisms of power and thereby selectively bring forth specific values, norms, ideologies, beliefs, and theories in discourse (Wodak, 2004). Moreover, the processes of power discourse, therefore, bring about specific subjectivities which in turn shape actions and behaviours.

Similarly, the field of Orientalism has been made with a collective, colonial effort, but adopting a selective approach, to perpetuate the colonial rule and interests (Said, 2016). The colonial context, attitude, mindset, ideologies, norms, values, and theories must have exercised their influence in the creation of orientalism. The hermeneutics of the colonial discourse is, in fact, based upon the power relations of 'the dominant' and 'the dominated' (Said, 2016). In order to achieve the thematic ambition of power relations, the colonial writers have usually relied upon the linguistic binaries. Since these mechanisms of orientalist discourse play a highly important role in the policy formation and construction of subjectivities, behaviours, and actions, it is quite significant to deconstruct the discourse of power by employing Wadak's discourse analysis method.

Since the field of Orientalism has a very vast scope, the current research assignment is delimited only to Bernard Lewis' essay, The Roots of Muslim Rage. Bernard Lewis, a British-born American, has written extensively on the themes of orientalism. The publication of this essay, in the context when the Soviet Union was breathing it's last and the new world order was being designed, is so much significant in both political and ideological terms. Besides, this essay is a systematic, scholarly attempt to shape the world order on a new ideological basis by borrowing from the historical narratives of Orientalism. This essay is, in fact, a social practice that aims to establish the world order based upon the orientalist binaries of 'good' and 'evil'. In Bernard Lewis' world of binaries, the former represents the West, whereas the latter 
represents Islam.

Discussed above, the discourse of Orientalism is a social practice that is molded by political, religious, or economic ideologies, it is highly helpful to treat it as a biased practice (Wodak, 2004). This discourse of selectivity really excludes the alternative discourses of reality; it claims the only access to reality and truth. Because these discourses of power are either plausible or implausible, it is necessarily inevitable to employ Ruth Wodak's Discourse Historical Model (2004) to expose their ideological bias. Hence, the research assignment is assessing Bernard Lewis' essay by using Wodak's model of critical discourse analysis.

The researchers have dealt with the essay, The Roots of Muslim Rage using the Discourse Historical Model. Additionally, this method involves an analysis of hermeneutics, historical processes, social norms, and ideologies which play a significant role in creating discourse. Apart from critically dealing with the construction of the discourse, this method also takes into consideration the subjective interpretations that mostly reflect implausibility. Firstly, the researchers look at the essay through Wodak's lens. Then, he tries to explore the hermeneutics that is operating behind the textual representation of reality. Finally, the researcher categorizes the hermeneutics either plausibly or implausibly. Thus, the Discourse Historical Model has been used to understand critically the processes of discourse formulations.

\section{Problem Statement}

Discourse is neither right nor wrong; it is either plausible or implausible (Wodak, 2004). It involves hermeneutic interpretations which are influenced by historical processes, power relations, social norms, and ideologies (Wodak, 2004). It is, no doubt, in the general interest to expose these processes of misrepresentation. Similarly, Bernard Lewis has deliberately resorted to the hermeneutics to distort the real image of the Islamic Orient. Hence, the researchers have chosen Wodak's Discourse Historical Model (2004) to topple down Lewis' implausible hermeneutics.

\section{Significance of the Study}

The significance of the current research assignment lies in its approach of exposing the implausible hermeneutics used by Bernard Lewis to perpetuate certain truths and interests; moreover, it also highlights the selective process of power that involves claims of specific realities. Besides, the current research paper will serve as a tool for countering the unquestioned truth narratives and hermeneutics. Similarly, it will also contribute to the field of critical discourse analysis in challenging the implausibility of discourses. Much more importantly, this research attempted help students in general and readers of Bernard Lewis in particular, not to take any piece of discourse for granted, and thereby it will help resist the constructionist role of these discourses in our society. 


\section{Research Objective}

This research attempted aims to analyze the hermeneutics in Bernard Lewis' essay: The Roots of Muslim Rage.

\section{Research Question}

The current research addressed the following question: How does the process of hermeneutic interpretation take place in Bernard Lewis' essay: The Roots of Muslim Rage?

\section{LITERATURE REVIEW}

The critical discourse analysis is a reversal, discontinuity process of resisting the power mechanisms of discourse (Hook, 2007). Although Hook's research work brilliantly takes into consideration the internal and the external mechanisms of power using the Foucauldian notion of discourse, but it fails to situate the political context of the discursive construction. Hook's work is mostly psychological in its approach and analysis; it, defectively, dislocates the political exteriority in the discourse construction process.

Much more politically deconstructive than Hook's work is Frantz Fanon's notion of counter-discourse. In Fanon's view, discourse serves as a battlefield where power struggles constantly take place (Fanon, 1994). His deconstruction of the French colonial discourse and construction of the Algerian freedom discourse clearly imply that discourse is a process of resisting the colonial hegemony of discourse (Fanon, 1994). Fanon means to say that discourse of resistance actually engenders the construction of those 'individuals' who challenge and at last topple down the oppressive powers of colonialism and its discourse. However, Fanon's idea is highly significant for the discourse of resistance, yet his deconstructive approach is very much limited to the discourse of colonial subjectification.

Unlike Fanon, Said, (Edward, 2016) has realistically voiced the post-colonial concerns while toppling down the Western discourses of power about the subjectification of the Orient. Said cogently asserts that from the 1750s up till now, Orientalism has enabled the West to inflict Oriental subjectification upon the people of the East (Said, 2016). In his seminal work, Orientalism, Said impressively excavates the power and discourse relation; he traces the relation successfully back to Aeschylus' The Persians. Moreover, he also identifies the marking features of Orientalism within the modern fields of American social sciences. The Saidian analytical approach is not only confined to Foucauldian notions of power and discourse, but he has also brilliantly assimilated the Gramscian notion of exposing the power structure of the 'essentially' established, Western discourses about the East. Besides, Said also borrows the non-essentialist approach of anti-dynastic intellectualism by Vico, Giambatista, an Italian scholar, to dismantle the Western discourses about the Orient. Though Saidian approach is much more scholarly and 
learned, yet his argumentative insistence mainly focusses on the discursive linearity of Orientalism.

Discourse is not only colonially inspired, but also politically motivated and exclusive. The discursivity of political exclusion is critically studied by (Whitaker, 2005) in Zambian setting. The focus of her study is centred to the discourse of political exclusion selectively employed by the Zambian politicians who approach legal institutions to 'subjectify' their political rivals as 'aliens' and thereby deprive them of the basic citizenship rights. She argues intellectually that the discourse of political exclusion is a serious threat to Zambia's democratic development, and it may sow the seeds of political chaos and civil disturbance. The research work of Whitaker mainly discusses the exclusive aspect of power. Even though she is mostly concerned with the exclusionary side of political discourse, yet she fails to offer the discourses of assimilation and co-existence. She merely laments the 'discursive outadministration' of the politically oppressed 'subjects' of Zambia, but one can find no trace of alternative, discursive narratives in her research work.

Apart from politically excluding the Zambian subjects, the disciplinary mechanisms of discourse also play a significant role in the realm of media. The mechanisms of power discourse are highly operational in the case of media. The disciplined construction of subjects and truths by media discourse perpetuates certain interests. Media constantly propagandizes certain agendas until these agendas become socially accepted truths. The selective representation of reality through media discourse entails desired subjectivities which, therefore, become social actions and behaviours. This subjectification on the part of media engenders a mindset in the audience which has been called 'manufacturing of consent' by some American intellectuals (Bennet, Herman, \& Chomsky, 1989). Besides, this analysis of media discourse is American-centric in its approach and content; the scholars have hardly given any space to the power discourses of media outside the American context. This indeed is much defective on media critics' part when it comes to countering the discourse of exploitation and subjectification.

Similarly, discourse also imposes its norms and values upon the will of common people. These controlled wills are meant to imply freedom of thought. This imposition of discursive confinement upon thoughts, wills, actions, and behaviours of people has been defined as 'dehumanizing' by (Kattakayam, 2006). He has adopted deliberately the post-modern approach to reveal the power mechanisms of discourse that ultimately shape and design subjectivities. Moreover, the researcher has availed no opportunity of presenting counter-will that always challenges the established will to power, the will which in Foucauldian terminology formulates 'episteme' of knowledge or discourse (Foucault, 2012). Sometimes it happens that not suggesting any counter-discourse strategy idealizes and stresses the established discourse of power.

As power discourse plays a vital role in shaping subjectivities, it also contributes significantly to the making of world orders. The state-sponsored 
discourse, especially in the case of a powerful state, paves the way for policy formulation and thereby it abundantly helps in bringing forth the desired world orders. (Chomsky, 1992) cogently argues that the American establishment employed discourse as a tool to construct a new world order that stood upon the binary oppositions of the Western good and the Communistic evil. These discursive binaries helped America to create pretexts for the Cold War and thereby the discursivity also justified her military interventions in so many countries of the world. Hence, the power of discourse brought forth both international state behaviors and international structure.

Much like Chomsky's obsession with power discourse is Spivak's consciousness of 'othering' a subaltern. A subaltern, in her view, is the most suppressed subject of society. The subaltern is excluded, othered, suppressed, outcast, and silenced in discourses of power (Spivak, 2017). In her views, the subalterns, particularly, women, have been historically silenced in the discourse of representation and thus they cannot voice their concerns. Both colonial and post-colonial discourses of power, she means to say, have 'rendered' women as silent subjects. In brief, she means to imply that the subaltern cannot speak. Although Spivak's analysis of the subaltern's subjectification through discourse is quite revealing, it is hardly acceptable that the subaltern cannot speak her concerns.

In Ruth Wodak's view (2012), the historical processes, social norms, and values and hermeneutic interpretations create discourse. However, much research work has been carried out on the discourses of Orientalism from cultural, economic, and anthropological perspectives, but when it comes to critical discourse analysis not much work has been done. Thus, the researcher has adopted Wodak's critical discourse analysis method to analyse Bernard Lewis' essay: The Roots of Muslim Rage. The justification of using this theoretical framework is that it critically exposes historical processes, societal norms, and subjective interpretations that generate discourse (Wodak, 2004). Discourses of power are highly biased, as they engender certain subjectivities, interests, behaviours, world orders, and above all social truths. Hence, it is highly useful to challenge their claims so that people can critically understand the power processes of discourse that fabricate realities. Thus, the aim of this research is to deconstruct Lewis' essay, The Roots of Muslim Rage, using Wodak's framework of CDA.

\section{RESEARCH METHOD}

The current research work is qualitative in its contents and analysis as it answers research questions. Moreover, the researchers used descriptive and explanatory research design, because it is very helpful in exposing the norms, values, historical processes, and interpretations that produce discourse as suggested by Wodak (2004). Besides, the researcher used purposive sampling to choose relevant chunks from Lewis' essay. Purposive sampling makes data analysis much relevant to 
research objectives. Through purposive sampling, the researchers chose lexical and syntactic units from Lewis' essay to do critical discourse analysis. Furthermore, the researcher selected eight chunks from Lewis' essay to do the critical analysis.

The researchers also coded the chunks and thus formulated much broader thematic categories. After coding the data, the researcher made us of Wodak's CDA (2004) theoretical framework to critically analyze the data.

\section{Theoretical Framework}

(Wodak, 2004) has given a Discourse Historical Model which is described here:

In Wodak's words, power relations, norms, values, and ideologies influence the production of discourse. She means to imply that the production of discourse is subject to societal relations and rituals. Whenever someone speaks or writes anything, the person actually reproduces cultural norms and social relations in his or her discourse.

In addition to power relations and social norms, the historical processes also affect the production of discourse. Discourse is impacted by both the synchronic and diachronic processes of history (Wodak, 2004). Synchronically, the discourse in question interacts with a similar type of contemporary discourses that justify its validity and provide it with vitality. Moreover, the discourses of the past (diachronic) also influence the production of contemporary discourses. Thus, discourse also interacts with its past to justify its claims.

Similar to the historical processes, the hermeneutic approach also impacts the production of discourse. The hermeneutic approach encourages subjective interpretation of other discourses or experiences. One person's hermeneutic interpretation of a phenomenon might be different from another person's interpretation of the same phenomenon. Besides, the interpretation can either be more plausible or less plausible; its wrong to say that one interpretation is wrong and the other is right (Wodak, 2004). Thus, discourse is a subjective interpretation that varies from one person to another person.

\section{FINDINGS AND DISCUSSION}

\section{Critical Discourse Analysis}

In this segment, the researchers have carried out a critical discourse analysis of Bernard Lewis' essay: The Roots of Muslim Rage using Wodak's Discourse Historical Model.

\section{Muslim: An Orientalized Subject}

Discourse involves power relations, social norms, historical processes, and hermeneutic interpretations which create spaces for subjects (Foucault, 2012). A subject is not necessarily an embodiment of a real individual. The subject is a 
discursive possibility that emerges or caused to emerge in a historical context. This discursive process of constructing subjects is precisely called subjectification. The mechanism of subjectification is a discursive tool that represents power relations and social norms. Similarly, orientalising involves discursive subjectification of the Muslims. The very title of Lewis' essay The Roots of Muslim Rage, is a diachronic attempt of orientalising all the Muslims of the world. The selectivity of the above title with the collocation 'Muslim Rage' represents norms and values of Orientalism. Moreover, this title actually 'forms a value' which enables the essayist to 'normalize' the subjective construction of the Muslims as enraged beings; thus, it is 'rage' that discursively 'interprets' a Muslim way of life. In a hermeneutic interpretation, Lewis attempts to impose religiosity upon the feelings of rage. Lewis is trying to forcefully convert the enraged feelings to Islam. Furthermore, this implausible interpretation, to borrow Wodak's terminology, subjectifies the Muslims as enraged individuals by excluding a much more plausible interpretation of Islam.

$$
\text { "...it inspired in some of its followers a mood of hatred and violence." }
$$

\section{(Lewis, Bernard, 1990)}

Similarly, Lewis's implausible interpretation of Islam continues in the above textual construction. The oriental norms and values make room for the negative terminology, such as 'a mood of hatred and violence' and construct, discursively, Muslim subjects who are 'inspired' by the violent teachings of Islam. Besides, this power discourse systematically reduces the positive interpretation of Islam and its teachings. Much more precisely, this discursivity implausibly interprets the Muslims as violent followers of Islam; it offers no space to the other side of the truth about the Muslims. Lewis' stereotypical approach towards Islam is revealed by his assertive 'normalization' that Islam is a system of beliefs that inculcates in its followers or subjects the teachings of violence and intolerance against the people of other faiths. This process of discursive normalization, in fact, bypasses, the plausible interpretations of Islam. Additionally, as (Wodak, 2004) said, the subjective interpretation of the so-called 'truth' entails the process of Muslim orientalising. Besides, this orientalised subjectification assigns the spaces of intolerance and violence to the Muslims to be occupied in orientalism. Hence, the oriental interpretation paved the way for American policymakers to design a new world order in which the Muslims were made to occupy the place of 'violent subjects' through the historical processes (Wodak, 2004).

"The Muslim has suffered the successive stages of defeat..."(Lewis, Bernard,

This orientalising process of power discourse includes yet another stereotypical statement about the Muslims. Lewis claims that a Muslim lacks morale to win a battle of life. The discursive attempt of associating the Muslims with defeat, thus, in much clearer terms Islam with weakness, reveals the hermeneutic approach of power discourse. By creating the discourse of Muslim weakness, Lewis wants to 
create such subjects as they accept their defeat owing to their religious traditions. Hence, Lewis is indirectly persuading Muslims to accept his 'hermeneutic interpretation and ideology' of American exceptionalism. Thus, he is trying to contribute to the political norms of the new world order, hegemonized by America, in which the Muslims are subjected to the American, cultural invasion. In short, he means to claim if the Muslims fail to comply with orientalist 'social norms', they exist as defeated subjects.

"...yet the generalized resentment of fundamentalists and other extremists against the West and its friends remains and grows and is not appeased." (Lewis, Bernard, 1990)

The above statement reduces the 'plausible interpretations of discourse' (Wodak, 2004). It merely favours the norms, values, ideologies, interpretations, and ambitions of the discourse manufacturer. The phrases, such as 'the generalized resentment' 'of fundamentalists', and 'other extremists' are discursive choices regulated through the power of inclusion. The first phrase is mainly concerned with resentment. The orientalising discourse implausibly places the Muslims within the slots of resentment, fundamentalism, and extremism. Moreover, the force of Muslim fervour keeps increasing with no intervention of appeasement. Lewis' hermeneutic approach perpetuates the subjectivities of the Muslims as Wodak (2004) discussed. The hermeneutic interpretation excludes the liberal aspects of Islam. Since discursive manipulation validates certain versions of the truth, Lewis is mainly concerned with misrepresentation of Islam so that a pretext can be created which enables America to interfere with the internal affairs of those countries where the Muslims are in majority. This, of course, has been the case in many of the Muslim states. Thus, a Muslim is made to emerge as a fundamentalist and extremist subject through the hermeneutic interpretations of Orientalism (Foucault, 2012).

"The treatment of women in the Western world...Christendom...even at its worst was rather better than the rule of polygamy and concubinage..."(Lewis, 1990)

Comparing women's treatment in Christianity and Islam, Lewis is employing the subjective interpretation of the Muslims as proponents of polygamy and concubinage. He is implausibly substituting the rule of Islam with the rule of polygamy and concubinage. Lewis' discursive construction of women's mistreatment in Islam systematically excludes women's higher status in Islam that challenges and destabilizes the power and meaning of Lewis' orientalised discourse. Thus, the ideology and power relations of orientalism make it implausibly possible for Lewis to address the Muslims as polygamists, those who advocate or do more than one marriage, and supporters of concubinage. Hence, Lewis is subjectifying the sexuality of the Muslims collectively. Moreover, the author's reduction of contingencies systematically excludes the way many Christian priests cruelly inflicted witch-trials upon the women of the Middle Ages. This shows that the hermeneutic interpretations are influenced by religious ideologies as well. Thus, the Muslims have been subjectively orientalised as polygamists and proponents of concubinage. 


\section{The Construction of Monolithic Categories through Hermeneutic Interpretation: the Muslims and the West}

Lewis' hermeneutic interpretation is characterized by the construction of monolithic categories. The monolithic categorization is itself a discursive mechanism in which diversity of truths, the complexity of differences, and variety of identities are unjustifiably classified under simplistic terms of 'the West' or 'Islam'. Furthermore, this discourse of much more simplistic binaries mostly enables the writers to do hermeneutic interpretations. The categories are not embodiments of realities, but they are actually plausible or implausible interpretations of specific 'truths. Moreover, the hermeneutic process, in fact, subjectifies, simplistically, the Muslims, and the West. Besides, this subjectification is orientalised in its form and content. The orientalised interpretation illegitimately associates negative stereotypes with the Muslims and positive cults with the West. The binarization hardly assimilates the processual construction of alternative discourses. The hermeneutic interpretation excludes the Muslims of the West and the Christians or the Jews of the East. It simply treats the world in particularized, religious categories, while the essential diversity is backgrounded by the discourse of orientalism.

"The Azerbaijani movement has more in common with the liberal patriotism of Europe than with Islamic fundamentalism." (Lewis, Bernard, 1990)

The monolithic categorization is under process in the above-given extract from Lewis' essay. Lewis hermeneutically categorizes the whole of Europe as 'liberal', whereas the labels Islam as 'fundamentalist'. The discursive strategy of positive-self-representation and negative-other-representation further exposes Lewis' hermeneutics. In Wodak's views, discourse subjectively constructs one's positive self-image and other's negative image. Thus, discourse is a two-way process. Besides, Lewis means to imply subjectively that every Muslim is a fundamentalist, while every European is a liberal. This monolithic categorization reduces the plausible contingencies of diverse reality because of the discursive process backgrounds not only the Western fundamentalists and the white supremacists but also the peaceful Muslims. Even Lewis' hermeneutics quite clearly show that political movements get inspiration from the Western liberalism. But the 'the hermeneutic approach' excludes the differences which could challenge Lewis' monolithic validation of liberal epistemes (Foucault, 2012). Thus, in Wodak's terms, the hermeneutic interpretation legitimizes power relations, ideologies, and social norms.

"Western capitalism and democracy provide an authentic and attractive alternative to traditional ways of life." (Lewis, 1990)

He hermeneutically suggests that the West owns the political system of democracy and the economic system of capitalism. He is normalizing the hermeneutic interpretation that every Westerner is sophisticated and adores both capitalism and democracy. Contrarily, he also means to overgeneralize that every Eastern Muslim, who deviates capitalistic epistemes, is traditional and 
unsophisticated. Moreover, his hermeneutically asserts that both the systems are highly beneficial alternatives for the world's countries. This monolithic subjectification excludes plausible contingencies of interpretation, such as diversity, complexity, and variety of reality. Using the tool of hermeneutic interpretation, Lewis is actually trying to sell America's political norms and values to the world. In this way, Lewis' hermeneutics monolithically 'perpetuates' implausible hermeneutics of the Muslims and the West as (Wodak, 2004) has revealed.

\section{Discursive Construction of Paranoid Subjects}

The very word, paranoia, precisely implies hatred or fear from those people who belong to other countries or those who profess different religions. One who suffers this psychological disorder tends to suspect the loyalty of other nations; this disbelief is mostly tinged with the tendency of asserting that certain people are going to invade his or her country. Precisely speaking, paranoia is a discursive construction mostly employed by powerful countries, such as the United States of America with a view to creating a pretext of attacking and controlling the energy-rich countries across the world. Thus, the discourse of paranoia helps achieve this goal. Lewis is also advocating for this goal in the known essay. He is hermeneutically creating the feelings of fear in the Western people against Muslims and Islam. Islamophobia is, thus, a subjective construct brought forth by Lewis-type authors. Thus, he keeps asserting that the Muslims are to scatter in on the Western countries by highlighting the terminologies, such as 'the house of unbelief', or 'the house of war'.

"There is a surge of hatred that distresses, alarms, and above all baffles Americans." (Lewis, 1990)

Lewis has deliberately chosen the negative verbs, such as 'alarms', 'baffles', and 'distresses' to activate the mechanisms of paranoia in the Americans. The demonstrative word 'there' points to the exteriority of discourse, which refers to the Muslim world. This hermeneutic construction of the Muslims' world is linked with fear and threat that is currently undergoing 'a surge of hatred'. While on the other side, the Americans are being subjectified as innocent citizens who are to be attacked by violent Muslims. The mechanism of paranoia, over here, is discursively subjectified through the binaries of innocence and violence; consequently, this hermeneutic approach engenders the paranoid subjects who are given to the feelings of Islamophobia. Hence, Muslims have been subjectified to fit into oriental norms and values.

"And in the meantime, we must take great care on all sides to avoid the danger of a new era of religious wars..." (Lewis, Bernard, 1990)

The paranoid subjectification systematically continues in the above lines. Now, Lewis has gone, carefully, a step ahead to invocate the country of his allegiance, the United States of America to take lead in world affairs by preventing the new era of 'religious wars'. This role of leadership involves economic, political, cultural, and historical 'hegemonization' of world affairs. Moreover, he has employed 
the plural pronoun, 'we' to assert a responsibility of power on America's part in international affairs. Similarly, the construction of paranoid subjects by employing the concept of religious wars enables Lewis to construct 'the hermeneutic interpretation' of America as the world's saviour. Besides, the discourse of paranoia and subjectification, in fact, excludes the plausible contingencies of mutual trust, altruism, and universal brotherhood that all the world's religions are teaching their followers. This paranoia is a subjective construction that offers no space to peace and mutual understanding. Furthermore, Lewis makes no mention of civilizational interaction through mutual understanding and interfaith harmony. Thus, this hermeneutics of fear, as Wodak (2004) said, creates consent among Americans that consequently shapes their actions, behaviours, and world affairs. Thus, the hermeneutics of paranoia has helped Lewis to propagate for American interests at the cost of general interests.

\section{CONCLUSION}

The current research has studied Bernard Lewis' essay: The Roots of Muslim Rage by employing Wodak's Discourse Historical Model. The research findings have revealed critically that discourse is a hermeneutic process that can either be plausible or implausible. The social norms, values, relations, ideologies, and historical processes impact the production of discourse. Similarly, Lewis has orientalised the Muslims through hermeneutic interpretations. Moreover, this research is a human effort that is open to faults and defects, therefore, it makes no claims of perfection. Besides, this research has its own gaps and faults that might be improved through further criticism. Furthermore, this research work will be a helpful tool for those scholars of critical discourse analysis and students who really want to understand critically the power mechanisms of truth making processes through discourse. Similarly, this research attempt will also contribute to the field of critical discourse analysis. The research assignment also deconstructs the policymaking process by exposing the interest-oriented mechanisms of power. Thus, this research assignment has revealed the other side of truth in Lewis' essay by making use of Wodak's Discourse Historical Model (2004).

\section{BIBLIOGRAPHY}

Chomsky, N. (2011). Deterring democracy. Random House.

Fanon, F. (1994). A dying colonialism. Grove/Atlantic.

Foucault, M. (2012). undefined. Vintage.

Foucault, M. (2012). The history of sexuality: An introduction. Vintage.

Herman, E. S., \& Chomsky, N. (2011). undefined. Pantheon. 
Hook, D. (2007). Discourse, knowledge, materiality, history: Foucault and discourse analysis. Foucault, Psychology and the Analytics of Power, 100-137. doi:10.1057/9780230592322_4

Kattakayam, J. J. (2006). Power and knowledge: Some reflections on contemporary practices. Sociological Bulletin, 55(3), 449-467.

doi:10.1177/0038022920060306

Chomsky, N. (2011). Deterring democracy. Random House.

Fanon, F. (1994). A dying colonialism. Grove/Atlantic.

Foucault, M. (2012). undefined. Vintage.

Foucault, M. (2012). The history of sexuality: An introduction. Vintage.

Herman, E. S., \& Chomsky, N. (2011). undefined. Pantheon.

Hook, D. (2007). Discourse, knowledge, materiality, history: Foucault and discourse analysis. Foucault, Psychology and the Analytics of Power, 100-137. doi:10.1057/9780230592322_4

Kattakayam, J. J. (2006). Power and knowledge: Some reflections on contemporary practices. Sociological Bulletin, 55(3), 449-467.

doi:10.1177/0038022920060306

Riach, G. (2017). Can the subaltern speak? CRC Press.

Said, E. W. (2016). Orientalism: Western conceptions of the Orient. Penguin UK.

Whitaker, B. E. (2005). Citizens and foreigners: Democratization and the politics of exclusion in Africa. African Studies Review, 48(1), 109-126. doi:10.1353/arw.2005.0047

Riach, G. (2017). Can the subaltern speak? CRC Press.

Said, E. W. (2016). Orientalism: Western conceptions of the Orient. Penguin UK.

Whitaker, B. E. (2005). Citizens and foreigners: Democratization and the politics of exclusion in Africa. African Studies Review, 48(1), 109-126. doi:10.1353/arw.2005.0047

Wodak, R. (2004). New directions in research on political discourse? Journal of Language and Politics, 3(1), 1-2. doi:10.1075/jlp.3.1.02wod 